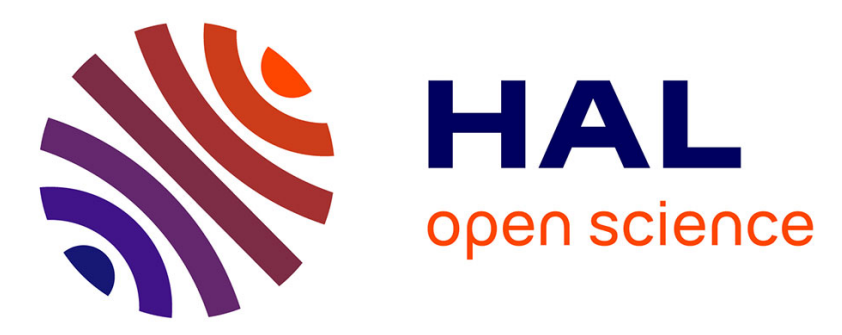

\title{
Crime, Inequality and Unemployment in England and Wales
}

\author{
Dongxu Wu, Zhongmin Wu
}

\section{To cite this version:}

Dongxu Wu, Zhongmin Wu. Crime, Inequality and Unemployment in England and Wales. Applied Economics, 2011, pp.1. 10.1080/00036846.2011.581217 . hal-00712374

\section{HAL Id: hal-00712374 https://hal.science/hal-00712374}

Submitted on 27 Jun 2012

HAL is a multi-disciplinary open access archive for the deposit and dissemination of scientific research documents, whether they are published or not. The documents may come from teaching and research institutions in France or abroad, or from public or private research centers.
L'archive ouverte pluridisciplinaire HAL, est destinée au dépôt et à la diffusion de documents scientifiques de niveau recherche, publiés ou non, émanant des établissements d'enseignement et de recherche français ou étrangers, des laboratoires publics ou privés. 


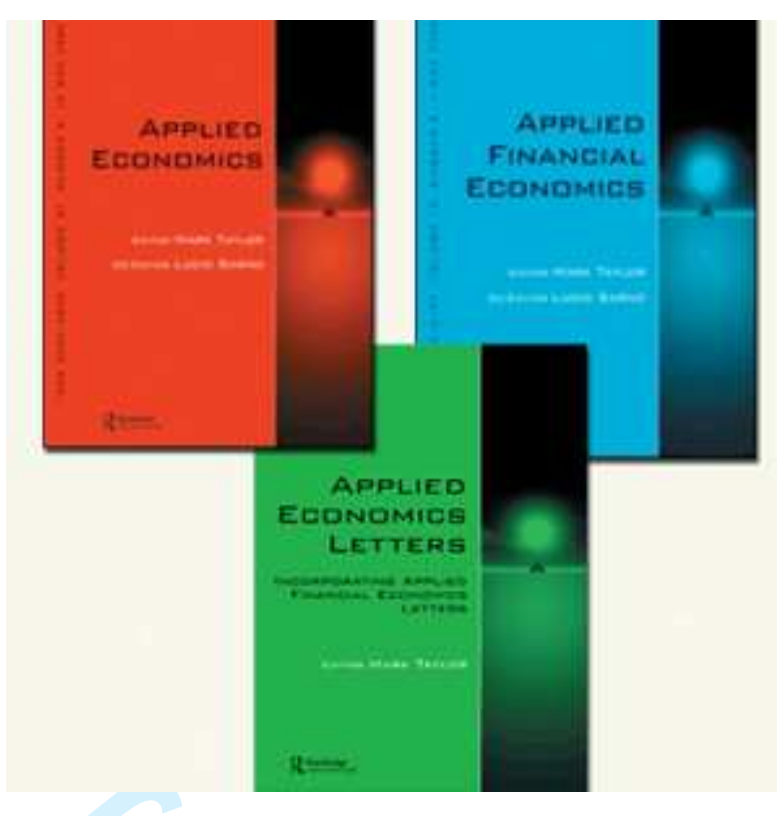

Crime, Inequality and Unemployment in England and Wales

\begin{tabular}{|c|c|}
\hline Journal: & Applied Economics \\
\hline Manuscript ID: & APE-2009-0687.R1 \\
\hline Journal Selection: & Applied Economics \\
\hline $\begin{array}{l}\text { Date Submitted by the } \\
\text { Author: }\end{array}$ & 05-Oct-2010 \\
\hline Complete List of Authors: & $\begin{array}{l}\text { Wu, Dongxu; Cambridge University, Fitzwilliam College } \\
\text { WU, Zhongmin; Nottingham Business School, Economics }\end{array}$ \\
\hline JEL Code: & $\begin{array}{l}\text { D63 - Equity, Justice, Inequality, etc. and Measurement < D6 - } \\
\text { Welfare Economics < D - Microeconomics, J39 - Other < J3 - } \\
\text { Wages, Compensation, and Labor Costs < J - Labor and } \\
\text { Demographic Economics, K42 - Illegal Behavior and the } \\
\text { Enforcement of Law < K4 - Legal Procedure, the Legal System, and } \\
\text { Illegal Behavior < K - Law and Economics }\end{array}$ \\
\hline Keywords: & Crime, Income Inequality, Unemployment, Panel Data, UK \\
\hline
\end{tabular}

\section{SCHOLARONE ${ }^{m}$ \\ Manuscripts}




\title{
Crime, Inequality and Unemployment in England and Wales
}

\author{
Dongxu $\mathrm{Wu}^{\mathrm{a}}$ and Zhongmin $\mathrm{Wu}^{\mathrm{b}}$ * \\ ${ }^{a}$ Fitzwilliam College, University of Cambridge, UK \\ ${ }^{\mathrm{b}}$ Nottingham Business School, Nottingham Trent University, UK
}

\begin{abstract}
A model of crime is developed based on principles from the existing literature with some original insight. The implications of the model are that income inequality and unemployment are important explanatory variables for crimes motivated by economic gain, but do not offer much explanatory power for other types of crime. A panel data of UK regions over the years from 2002 to 2007 is then used to test these predictions. The empirical results strongly support the hypothesis that crime is an economic phenomenon.
\end{abstract}

\section{Introduction}

Economic activity is characterised by mutually beneficial trades. In contrast, crime is non-consensual and always involves an unwilling participant (victim). In this sense, crime appears to be beyond the realm of economic analysis. Despite this apparent mismatch, the economic approach to crime has made increasing contributions to the study of crime.

Crime, defined as a violation of the law, is a problem that afflicts all societies and countries though to varying degrees. It is seen as the top national problem in most

*Corresponding author, Email: zhongmin.wu@ntu.ac.uk 
Latin America countries and in many Asian and African countries. ${ }^{1}$ In the 2008 UK budget, $£ 33$ billion was allocated to Public Order and Safety. It is also continuingly growing as a share of total expenditure from $4.5 \%$ in $1987-1988$ to $5.8 \%$ in 2007 2008. ${ }^{2}$ This is dwarfed by the figures from the United States. The Bureau of Justice Statistics estimates that nearly $\$ 200$ billion is spent each year in the United States to catch, prosecute, and punish offenders. The total cost of crimes, which include private protection and damages caused to the victims is much higher.

Braithwaite (1979) surveyed 51 studies and concluded that 'lower class' people have higher official crime rates than other groups. It reveals that crime is mainly conducted by those who are less well off in society. People on low income, the unemployed, those with little formal education, come from broken homes are far more likely to be convicted of a crime.

Following the pioneering work of Becker (1968), economists have increasingly ventured into the field of crime with the tools of economics and produced important results in both the determinants and consequences of crime. What distinguishes the economic approach to the study of crime from other disciplines is an emphasis on the role of incentives in determining behaviour of individuals and the use of econometric techniques in differentiating causality from correlation. While it is true that many crimes are acts of impulse or rage, rational human behaviour where individuals maximise their utility given the constraints they face is still a plausible generalisation.

This paper is both a theoretical and empirical investigation. A model of crime is set out which is based on the principles from the existing literature with some original insight. The implications of income inequality and unemployment of this

\footnotetext{
${ }^{1}$ Pew Global Attitudes survey http://pewglobal.org/

${ }^{2}$ Calculated from HM Treasury data
} 
model is then tested using empirical evidence from the UK. There have been numerous studies on the effects of inequality or unemployment on crime in the US. This is in stark contrast to the UK where there has only been few papers on these topics and most of them date back to the 1990s.

The remainder of this paper is organised as following: Section 2 critiques the current literature regarding income inequality and unemployment as determinants of crime. Section 3 develops a model for economic crimes and a model for non economic crimes. Section 4 is data description. Section 5 shows the empirical findings, and Section 6 concludes.

\section{Literature Review}

The economic literature addressing the relationship between crime and various measures of deprivation such as economic inequality and unemployment is extensive. This literature review does not attempt to be exhaustive, but rather, gives an overview of the main works and provide a brief discussion of the most relevant literature concerning economic inequality and unemployment as determinants of crime.

The frequency of which Becker (1968) is cited in economic papers of crime is astonishing. Becker revived the then forgotten cost benefit analysis idea postulated by Bentham in the $18^{\text {th }}$ Century $^{3}$. Becker presented the first modern economic model of criminal behaviour where a crime is committed when the expected gains exceed the expected costs of offending for the potential criminal. The assumption that criminals are rational individuals who maximise their expected utility subject to constraints

\footnotetext{
${ }^{3}$ The connection between crime and economics is as old as economics itself. Adam Smith (1937), in the Wealth of Nations noted that: "The affluence of the rich excites the indignation of the poor, who are often both driven by want, and prompted by envy; to invade his possessions... can be protected only by the powerful arm of the civil magistrate."
} 
forms the basis of the economic approach to crime, but this approach is often insufficient in explaining crimes of 'passion' such as assault, rape and murder.

The earlier economics work on crime tended to focus on the individual decisions of criminals (Ehrlich 1973, Block and Heineke 1975) as there was little data to conduct empirical analysis. Scholars such as Shavell (1991); Benoit and Osborne (1992) worked on optimal punishment. The more recent work on crime by economists has been more empirical than theoretical.

The relationship between income inequality and the incidence of crime has been heavily researched on by Economists, Criminologists and Sociologists alike. From Becker's model, to every other economic model that has come since, crime rates depend positively on the potential gains from crime. These gains can be represented theoretically by the wealth differences between the rich and the poor, as in Bourguignon (2000), or by the income differences among complex heterogeneous agents, as in Imrohoroglu et al (2000). Economic inequality has also been used to measure the difference between the gains from crime and its opportunity costs by Fleisher (1966), Ehrlich (1973), and more recently Kelly (2000).

Fajnzylber et al (2002) find that income inequality, measured by the Gini coefficient, has a significant positive effect on the incidence of crime across countries and over time. However, the conclusions drawn from any cross country studies are susceptible to attacks on the comparability of international data and on their ability to control for unobserved variables. For instance, Bourguignon (1998) argues that “...the significance of inequality as a determinant of crime in a cross-section of countries may be due to unobserved factors affecting simultaneously inequality and crime rather than to some causal relationship between these two variables." 
The empirical literature addressing the relationship between crime and inequality has produced mixed results. Ehrlich (1973) tested his theoretical model using FBI data and found a significant relationship between the crime rate and the share of the population below half the median income across the US states. Other cross-sectional studies have confirmed this relationship (see Freeman 1996). However, a number of other papers find statistically insignificant coefficients on income inequality (see Williams 1984).

Brush (2007) finds that the Gini coefficient is positively associated with crime rates in the cross section analysis, but negatively or insignificant associated with crime rates in the time series analysis. "These results suggest that greater attention should be given to identifying the many factors affecting crime before one concludes that income inequality is the culprit".

Dahlberg and Gustavsson (2008) argued that "income can be considered as consisting of two parts, one permanent and one transitory, and it is the changes in the permanent part rather than in the transitory part that affects crime rates". Their results "indicate that it is crucially important to separate the two effects".

The economic model of crime, such as Becker's (1968), predicts that deteriorating labour market conditions in the form of rising unemployment rates and falling wages of the unskilled increase criminal activity. Worsening legitimate labour market opportunities reduce the opportunity cost of crime. This prediction is more relevant for crimes involving direct financial gain such as robbery, burglary, vehicle offences and theft; but less important for assault, sexual offences and criminal damage. Controlling for other factors, most studies report a statistically significant but substantively small relationship between unemployment rates and property crime, see Gould et al (2002), Carmichael and Ward (2000), Donohue and Levitt (2001), and 
Raphael and Winter-Ebmer (2001). A typical estimate would be that a one percentage point increase in the unemployment rate is associated with a one percent increase in property crime (Levitt 2004). Reilly and Witt (1996) tested the predictions of Becker's economic model of crime using 42 police force areas over 12 years and found unemployment impacting positively on property crime.

Machin and Meghir (2000) utilised panel data and explored the role of changes in wages at the bottom end of the income distribution in determining crime rates. They used data on the police force areas of England and Wales between 1975 and 1996 and found that falls in the wages of unskilled workers led to increased crime. Witt et al (1998) used a panel of annual data from 1979 to 1993 for ten regions in England and Wales to examine the impact of the growth in earnings inequality and unemployment on five types of criminal activity. They found that 'changes in wage inequality and changes in unemployment are strongly and positively correlated with changes in crime.' Witt et al (1999) then conducted further investigation by using annual crime data from 1986 to 1996 for 42 police areas in the UK. They used a dynamic panel data model by generalised method of moments to correct for the bias generated due to the inclusion of a lagged variable. Again, they found high crime rates to be associated with high unemployment and high wage inequality. It was acknowledged that the study was limited by the unavailability of micro level data in the UK and the failure to control for endogeneity of the police force variable. Carmichael and Ward (2000) found that, i) there is a systematic positive relationship between burglary rates and male unemployment regardless of age; ii) youth unemployment is consistently and positively related to criminal damage and robbery rates; iii) a positive link between adult unemployment and theft. 


\section{Theoretical Model}

A model of crime is set out which is based on the principles formulated by Becker (1968), Ehrlich (1973), Freeman (1999) and Edmark (2005). Traditional criminology theory on the determinants of crime had focused on the deviant nature of the criminal. The emphasis was on characteristics which are unique to criminals. Factors such as biological inheritance, family background, social surroundings, cultural, disenchantment with society, were all used to explain the occurrence of crime. Most economic literature on this issue adopted the utility maximisation framework. The limitation of this approach is that only crimes where the rewards are pecuniary, such as theft and burglary, have strong theoretical foundations. While the model developed in this paper follows the economic approach of criminal rationality, criminology theories are incorporated where possible. This also allows for the explanation of crimes which are non-economic in nature such as assault and rape.

Of the Prison population in the $\mathrm{UK}^{4}$ :

- $67 \%$ were unemployed in the four weeks before their imprisonment, compared to $5 \%$ of the general population.

- $27 \%$ had been taken into local authority care as a child compared to $2 \%$ of children in the general population.

- $52 \%$ of the male and $71 \%$ of the female prison population have no education qualifications, compared to $15 \%$ of the general population.

Crimes with a clear economic motive: Robbery (2\%), Burglary (12\%), Offenses against Vehicles (13\%), other thefts (23\%) and Fraud and forgery (3\%) account for $55 \%$ of all police recorded crimes in 2007/2008. In the British Crime Survey of 2008, economically motivated crimes: Burglary (7\%), Vehicle-related theft (15\%) and other

\footnotetext{
${ }^{4}$ Reducing re-offending by ex-prisoners (2002) Report by the Social Exclusion Unit (SEU)
} 
thefts $(30 \%)$ accounted for $52 \%$ of all crimes. The picture of the typical UK criminal that emerges from these facts and figures is someone who is not too dissimilar to the average criminal any where else in the world. He is young, not well educated and most importantly with little legitimate prospects.

First, an economic model of property crime based on the existing literature is developed to explain economic crimes. Then a modification of this model is presented which can explain crimes where the gain is not pecuniary ${ }^{5}$. The key difference between property crime and other crimes is the nature of the rewards derived from the crime. The primary gain of property crime for the criminal is monetary. Following Becker (1968), Ehrlich (1973) and most subsequent economic models, crime is considered as a substitute for work under an occupational choice framework. For crimes which the primary benefits are not pecuniary, we assume these crimes are substitutes for leisure. A utility maximising individual allocates his/her time between work and leisure so that the marginal utilities from each activity is equalised.

Numerous legitimate models of crime exist. The model developed here allows for a clear exposition of the economic intuitions behind the rational criminality approach.

\section{The economic model of property crime}

Although criminals are known to combine economic crimes with legitimate jobs, under a one period uncertainty model framework, we assume that they have to make a choice between the two as a source of income ${ }^{6}$.

A utility maximising individual will commit an offense if the expected utility to him exceeds the utility he would derive from engaging in his next best alternative form of employment (opportunity cost of his time).

\footnotetext{
${ }^{5}$ To the best of our knowledge, this has not been attempted.

${ }^{6}$ Models where work and crime are combined exists; see Witte and Tauchen (1994) for example. For the purposes of showing the determinants of crime, a simple static model is sufficient.
} 


$$
E U_{c}>E U_{l}
$$

$E U_{c}$ is the expected utility from property crime and $E U_{l}$ is the expected utility from the next best alternative, i.e. legal work. A criminal thus differs from a non criminal not in his basic motivations but in his benefits and costs.

The expected utility from crime is a function of the expected benefits and costs of crime and the degree of risk aversion of the individual. Crime is a very risky activity where the returns vary greatly. Therefore, the degree of risk aversion is an important factor. If the individual choose to commit crime, there are two states of the world that he could find himself in. He could either be caught with probability $p$, or he is not caught with probability $(1-p)^{7} \cdot E U_{c}$ is therefore a probability-weighted average of the utility of the two states.

$$
E U_{c}=(1-p) U\left(W_{c}, E\right)+p U\left(W_{c}-F, E\right)
$$

Where $W_{c}$ is the monetary benefit of the crime, which is equivalent to the market value of the stolen goods. The size of $W_{c}$ depends on the wealth of the area. $F$ is the cost of apprehension. This is composed of fines, opportunity cost of time spent in jail, low standard of living in prisons, restrictions on future employment, damage to the person's social capital and reputation. These costs are only accrued if convicted. $E$ is the effort and psychic cost of crime. Meticulously planned burglary take much time and work, while petty theft maybe carried out only when the opportunity represents itself.

$$
\frac{\partial E U_{c}}{\partial p}=-U\left(W_{c}, E\right)+U\left(W_{c}-F, E\right)<0
$$

\footnotetext{
${ }^{7}$ In reality, a third state exists where the criminal is caught but not convicted due for example to a lack of evidence. For simplicity but without loss of generality, it is assumed that if a criminal is caught, he is convicted.
} 


$$
\frac{\partial E U_{c}}{\partial F}=-p U^{\prime}\left(W_{c}-F, E\right)<0
$$

The model predicts that the expected utility from crime will fall if the probability of arrest, $p$, or the cost of apprehension, $F$, is increased.

While the benefit of crime (monetary gain) is more or less fixed for any criminal, the cost is not. The opportunity of time spent in jail is far higher for an experienced and productive worker who is able to command high wages than it is for an uneducated and low productive youth. The cost of effort differs. Robbery is often very violent and the offender needs to make a quick get away. The physical nature of these crimes is part of the reason why most offences are by young men. Also, the moral cost of committing crime differs substantially and this is in part due to education and upbringing.

The cost to reputation, social capital and effects on future employment probably has the greatest deterrent effect on most individuals. Associated with this is the peer group effect, which is known to be a very important factor in determining crime. Different social networks have different attitudes to crime. For instance, the damage done to the reputation of an academic or a politician due to a crime conviction is far greater than for a teenage delinquent committing the same offence. Indeed, the teenager may gain more respect from his gang members as a result.

This model explains the prevalence of repeat offenders. Given the offenders' opportunities and preferences, it may be optimal for him to re-offend. Legitimate earning opportunities of convicted offenders may become much scarcer relative to their illegitimate opportunities because of the criminal record effect and the effect of long imprisonment terms on legitimate skills and employment opportunities. Once one is labelled as a criminal, further convictions do little harm to this already tarnished reputation. 
The expected utility from legal work, $E U_{l}$, is far less risky than crime but is by no means certain. We assume that at the beginning of the period, the individual does not know whether he will be employed or not. Again there are two states of the world if the individual choose to engage in legal activity and $E U_{l}$ is a probability weighted average of the two states ${ }^{8}$.

$$
E U_{l}=(1-u) U\left(W_{l}, H\right)+u U(B)
$$

Where $W_{l}$ is the wage (for unskilled workers) from legal income. Since most criminals are low productive, $W_{l}$ is likely to be far lower than the average wage. $u$ is the probability of unemployment, which is far higher than the unemployment rate for the entire population. $B$ is the unemployment benefits. $H$ is the effort that needs to put into work. The minimum wage is substantially higher than unemployment benefits $\left(W_{l}>B\right)$. Despite the cost of effort in honest work $H$, in general, $U\left(W_{l}, H\right)>U(B)$.

$$
\frac{\partial E U_{l}}{\partial u}=-U\left(W_{l}, H\right)+U(B)<0
$$

Increasing the probability of unemployment reduces the expected utility from choosing to participate in the legitimate labour market.

Thus, the individual will commit property crime if:

$$
(1-p) U\left(W_{c}, E\right)+p U\left(W_{c}-F, E\right)>(1-u) U\left(W_{l}, H\right)+u U(B)
$$

\section{Model of non-economic crime}

The primary motivation for crimes such as homicide and rape is psychological benefits to the criminal. Homicide may give the murderer some kind of thrill or the gratification of revenge. Assaults may give the offender peer approval or a sense of

\footnotetext{
${ }^{8}$ Note that $E U_{l}$ is an indirect utility function.
} 
accomplishment. Rape may satisfy the sexual desires of the criminal. The key point is that these crimes cannot be considered as a substitute for legal work. I propose that these crimes to be considered as a substitute for leisure.

A utility maximising individual will commit an offense if the expected utility to him exceeds the utility he would derive from engaging in his next best alternative form of leisure, such as watching television.

$$
E U_{n c}>E U_{e}
$$

$E U_{n c}$ is the expected utility from crime (non economic) and $E U_{e}$ is the expected utility from the next best alternative form of leisure activity.

$$
E U_{n c}=(1-p) U(Z, E)+p U(Z-F, E)
$$

Only one modification is made to the expected utility of economic crime to arrive at the expected utility of non economic crime. $Z$, which denotes the psychological benefits of the crime to the criminal replaces $W_{c}$.

$$
E U_{e}=U(X)
$$

$E U_{e}$ is a utility function of the next best alternative leisure activity $X$.

A criminal will commit the non economic crime if:

$$
(1-p) U(Z, E)+p U(Z-F, E)>U(X)
$$

\footnotetext{
Aggregate supply of crime

As the only available data for the UK is aggregate data, we need to find a function of aggregate supply of crime. An individual will commit an economic crime during the one period under consideration if equation (7) is satisfied. From this, a behavioural function relating participation in illegal activity, $O$, to its determinants can be specified.
} 
The sign underneath the variables indicates its effect on crime. An aggregation of each individual's participation in crime gives the total number of offences. As stated above, these variables will differ significantly between persons.

A higher probability of conviction implies that the condition for choosing crime will hold for a smaller number of individuals, and hence will decrease the aggregate supply of crime. Higher unemployment rate reduces the expected utility from legitimate work. The model thus predicts that higher unemployment will result in higher property crime rates. Higher income inequality will also cause higher property crime rate. As most criminals are not well educated and low productive, their job prospects are poor. They belong to the bottom end of the income distribution. The greater the income inequality, the greater the incentive to engage in property crime. Firstly, higher income inequality means the rich are a lot wealthier than the potential criminals. This means that there are greater monetary returns $W_{c}$ from committing crime. Secondly, higher income inequality means that those on the bottom end of the income distribution has low wages $W_{l}$. This reduces the opportunity cost of being convicted.

The behaviour relation for crimes not motivated by economic gain is:

$$
O=O\left(p, F, E, Z_{+}, X_{-}\right)
$$

Although unemployment and returns from legitimate and illegitimate activities do not enter into the equation directly, they are functions of the cost of punishment F. If future legitimate labour market prospects are poor, reflected in a high unemployment rate and a low legitimate wages for the unskilled, $W_{l}$, then the expected loss of future earnings due to a criminal record is reduced. Note that these effects were also present 
in the behaviour relation for economic crimes. This means that according to this model, income inequality and unemployment should affect crimes with economic motivation more than crimes without economic motivations.

\section{Hypothesis:}

1. Economic inequality and unemployment are good explanatory variables of crimes where the gain is economic in nature (Burglary, Robbery, Vehicles, Theft, Fraud, and Drug).

2. Economic inequality and unemployment are poor explanatory variables of crimes where the gain is not monetary (Sexual, Violence, Damage).

\section{The Data}

\section{Crime Data}

Data problems are the biggest obstacle to any study of crime. The very nature of crime means that data is unreliable. The perpetrators of crime go to great lengths to avoid capture. Many studies of crime using cross country analysis exists in the economic literature. These studies ignore the enormous variations in the reliability and comparability of crime data. The police forces in many developing countries are under funded while others are notoriously corrupt. In addition, police forces have a huge incentive to under report crimes in order to increase police clear up rates. When the time dimension is introduced, the problem is magnified. If recorded crime in the UK should not be compared before and after the introduction of the National Crime Recording Standard in April 2002, then cross country comparisons would be even more misleading. 
Crime data is available by police force which divides England and Wales into 377 areas $^{9}$. Crime data in this form has not been used in any economic studies to the best of our knowledge. Of the few UK studies of economic variables as a determinant of crime since 1990, three have used the second most comprehensive division of $42^{10}$. Two studies (Witt et al 1998, Machin and Meghir 2000) went on to use the New Earning Survey data on wages. This is problematic for a number of reasons. Firstly, the datasets are not an exact match with the crime data, which is acknowledged by the authors. Second and more importantly, the Annual Survey of Hours and Earnings (ASHE) itself states that these data are not reliable or have large variances unless the larger regions are used. This is especially the case for the wages at the $90 \%$ of income earners. Much of it is unavailable. This paper therefore used data which divided the UK into 10 regions (Government Office regions): North East, North West, Yorkshire \& The Humber, East Midlands, West Midlands, South West, East of England, London, South East, and Wales. This is a very popular division of the UK and data on many variables are published in this format.

Ten crime categories are considered in this paper. Robbery, burglary, offences against vehicles, other theft offences, fraud and forgery has a definite underlying economic motive. Violence against the person, Sexual offences and criminal damage are not economically motivated. While trafficking drugs offences would be considered an economic crime, the consumption of it would not. Other miscellaneous offences include the rest of the crimes. Total number of crimes in each region are divided by the population of that region then multiplied by 1000 to give the crime rate.

\footnotetext{
${ }^{9}$ This is not published but is available on request.

${ }^{10}$ London was excluded due to the low resident population which artificially inflates the crime rate per thousand populations (see Machin and Meghir 2004). Also, it is much smaller than the other regions (See Reilly and Witt 1996, Witt et al 1998).
} 


\section{Income data}

$\mathrm{ASHE}^{11}$ provides UK regional earnings data. Annual male wage data is used for the following reasons: young males commit the vast majority of crime both in the UK and the rest of the world. According to Dahlberg and Gustavsson (2008), permanent income inequality rather than transitory income inequality is the key determinant of crime; hence this paper uses the annual wage data ${ }^{12}$. Ideally, young males' wages of the 10 regions would be used. However, this was not available. ASHE has male earnings data by deciles. Following Witt et al (1998), wage inequality is defined as male annual earnings of the $9^{\text {th }}$ decile relative to the $1^{\text {st }}$.

\section{Unemployment data}

Unemployment data is constructed using ONS time series data. The Labour Force Survey provides unemployment data. Significant changes were implemented in 1999 which means that it is not comparable after this date. Male unemployment is used.

\section{Police data}

In both the static and dynamic version of the Becker (1968) economic model of crime, the cost of the crime to the criminal is a function of the probability of apprehension. The effectiveness of the police force should therefore be a determinant of the crime rate. The size of the police force or per capital expenditure on policing is generally used as a proxy for police effectiveness ${ }^{13}$. Many scholars noted the serious endogeneity problem. The crime rate is one of the major determinants of police force spending. Crime would be an important concern of citizens in a particular area if that

\footnotetext{
${ }^{11}$ Available on the ONS website.

${ }^{12}$ Witt et al (1998) used weekly

${ }^{13}$ See Witt et al (1998)
} 


\section{Population data}

The model presented in this paper is a microeconomic individual crime decision model. In order to derive the aggregate crime rates, region specific variables must be taken into account. Population density is included. Crime is most prevalent in densely populated areas as there are more potential victims. Population density data comes from the Office of National Statistics.

Crime statistics suggest that that most crimes are committed by young males. The empirical implication is that the higher the proportion of males aged between 14 and 29, the higher the crime rate per thousand populations. Intuitively, the greater the proportion of people with high offending likelihoods, the higher the expected offending rate. However, including this variable into our regression makes little sense. The proportion of young males is almost constant across the 10 regions of the United Kingdom ${ }^{14}$, and the variation within any particular year is less than $1 \%$. The effects of population proportions will be captured in the constant term. A cross country analysis of states with different types of population pyramid and varied population

\footnotetext{
${ }^{14}$ The UK is surprisingly homogenous in this respect
} 
distributions would likely yield significant results. Another problem is that the data is limited in length of the time period under study. Population distribution takes generations to change significantly. Also, once a country reaches a certain level of development, the population distribution would conform to a particular shape as both birth and death rates decline.

The cost of punishment, $F$, is omitted. As discussed in the previous section, $F$, the cost of punishment incorporates a diverse range of costs which are impossible to measure.

\section{Empirical specification of the model}

On the basis of the model developed in the previous section, a number of parameters are included when specifying a model for aggregate crime rates: income inequality (which measures the dispersion between income from legitimate activity, $W_{l}$, and illegitimate activity, $W_{c}$ ), unemployment, $u$, proportion of crimes solved by the police (sanctions detection), $p$, and population density, $D$.

The econometric model is thus:

$$
\ln \left(\frac{O}{N}\right)_{i t}=\alpha+\beta_{1} \ln \bar{W}_{i t}+\beta_{2} \ln u_{i t}+\beta_{3} \ln D_{i t}+\beta_{4} \ln p_{i t}+\varepsilon_{i t}
$$

The variables are in log form as this is the standard approach of most models in the existing literature.

\section{Dependent variables}

Crime rate, $\left(\frac{O}{N}\right)_{i t}$ : The number of crimes committed in a particular category per thousand populations living in area where the offence took place. 


\section{Independent variables}

Inequality, $\bar{W}_{i t}$ : Defined as the $10^{\text {th }}$ percentile male wage divided by the $90^{\text {th }}$ percentile male wage. Unemployment rate, $u_{i t}$ : ILO measure of male unemployment. Population density $D_{i t}$ : Number of people per square kilometre. Sanction detection rate, $p_{i t}$ : Percentage of recorded crimes 'cleared up' by the police.

Both inequality and unemployment are of males. This is because the vast majority of crimes are committed by males, hence isolating male inequality and unemployment should give us a better measure of their effects on crime.

\section{Random effects or fixed effects}

Population density, over a 6 year period is a time invariant variable for a given region. When the explanatory variable is constant over time, we cannot use Fixed Effects. A random effects panel is thus the most appropriate. Indeed, the fixed effects and random effects models gave similar results when population density is not included in the fixed effects model (See Table 1 and Table 2). However, when population density was included, the fixed effects model produced spurious results.

\section{Empirical Results}

The empirical results (see Table 1) provide strong support for the hypothesis. The inequality coefficients are positive and significant at the $1 \%$ level for all the economic motivated crimes (Robbery, Burglary, Vehicles, Theft and Fraud), while it is negative for the non economic motivated crimes (Violence, Damage, Drug, Other). A $1 \%$ increase in wage inequality will increase: robbery by $0.26 \%$, burglary by $0.44 \%$, vehicles by $0.4 \%$, theft by $0.17 \%$ and fraud by $0.62 \%$. 
Unemployment is only significant for Fraud, Drug and Other crimes. The coefficient of unemployment on Fraud is negative. This could be because higher unemployment increases the cost of being made redundant; hence employees are less likely to engage in fraud. It could also be due to those being made unemployed were the more likely to commit fraud. The coefficient of unemployment on drug is positive and significant at the 5\% level. A $1 \%$ increase in unemployment raises drug crime by $0.53 \%$. Losing one's job is a highly depressing event. Perhaps the unemployed are more likely to attempt escaping the reality facing them by taking drugs.

The coefficient of density is positive for all but Damage offences. This follows from theory and empirical evidence in the existing literature. The coefficient is at the $1 \%$ level of significance for Sexual, Robbery and Theft offences. These are the personal crimes where the criminal has to seek the victim. A mugger or a rapist is more likely to prey in urban areas where he is able to find a potential target. Searching for a victim in the countryside at night is unlikely to be fruitful.

The coefficient on detection is negative for most offences, as we would expect. It is significant at the $1 \%$ level for Robbery, Fraud, and Damage; and significant at the $5 \%$ level for Violence. Clearly, the criminal takes into account the probability that he is caught before he commits a crime. Another possibly explanation is that higher sanction detection rates lead to more criminals being imprisoned. These criminals cannot commit crimes while under incarceration, reducing the pool of criminals.

Results from the fixed effects regression excluding the population density variable (see Table 2) provides further support to the proposition that income inequality is a better explanatory variable for economic motivated crimes than for non economic crimes. The inequality coefficients are positive and significant for four of the five economic crimes at the $1 \%$ level, and at the $5 \%$ level for robbery. The 
inequality coefficient is statistically insignificant for sexual offences and damage. The detections coefficient is negative for most of the categories of crime as predicted by theory.

Table 3 shows that the econometric model is consistent and robust. Adding explanatory variables increase the explanatory power of the model (R-square) and increase the significance level for the inequality coefficient. Although the significance level of unemployment is reduced after adding detection sanctions, it is still significant at the $15 \%$ level.

Table 1, 2 and 3 together indicate that income inequality has a significant and positive impact on crimes of economic motivations. The results are robust to changes in the crime rate used (robbery, burglary, vehicles, theft, fraud), the set of additional variable explaining crime rates, and the method of econometric estimation.

The findings are consistent with other studies carried out in the UK in the mid 1990s. The most similar study was by Witt et al (1998), Carmichael and Ward (2000). The empirical findings from this paper are in more agreement with the economic models of crime than Witt et al (1998). This is possibly due to improvements in the accuracy of police recorded data, which has gone through two reforms since 1998. Also, sanctions detection rate was used instead of the size of the police force. This offers a better estimate of the cost of crime faced by the potential criminal and it suffers less from the well documented endogeneity problem of using police force size.

\section{Conclusion}

This paper investigated the validity of the economic approach to crime. Estimates based on UK annual regional data for the effects of earnings inequality and unemployment on various types of crime is presented. The results strongly support the 
implications of the economic model of crime developed in this paper. Hypothesis 1, which states that crimes motivated by economic gain are highly correlated with income inequality and unemployment, has been proven to be true. The results also support Hypothesis 2 which states that income inequality and unemployment are poor explanatory variables for crimes where the gain is non economic. The exceptionally robust results indicate there is a clear distinction between economic crimes and non economic crimes.

The weakness of the paper is that aggregate level data is tested based on micro level theory. Unfortunately, data at the micro level are simply not available in the UK. Another problem is the short length of the time period studied. This was due to the change in police recoding practices in 2002. Despite these weaknesses, this study confirms the potential of economic approaches to certain types of crime.

Crime is an economic phenomenon to the extent that the crime is motivated by economic gain. Property crimes are an economic phenomenon while non property crimes are largely not. 


\section{References:}

Becker, G. (1968) Crime and punishment: an economic approach, Journal of Political Economy 76 (2), 169 - 217.

Benoit, J. P. And Osborne, M. J. (1992) Crime, punishment and social expenditure, Journal of Institutional and Theoretical Economics, 326 - 347.

Block, M.K. and Heineke, J.M. (1975) A labor theoretic analysis of criminal choice, American Economic Review, 65, 314 - 325.

Bourguignon, F. (1998) Crime as a Social Cost of Poverty and Inequality: A Review Focusing on Developing Countries, Mimeographed, Development Economics Research Group, The World Bank, Washington, DC.

Bourguignon, F. (2000) Crime, Violence, and Inequitable Development, Annual World Bank Conference on Development Economics, 199-220.

Braithwaite J. (1979) Inequality Crime and Public Policy, Routledge and Kegan Paul.

Brush, J. (2007) Does income inequality lead to more crime? A comparison of crosssectional and time-series analyses of United States counties, Economics Letters 96 (2), $264-268$.

Carmichael F. and Ward R. (2000) Youth unemployment and crime in the English regions and Wales, Applied Economics, 32(5), 559 - 571.

Dahlberg, M. and Gustavsson, M. (2008) Inequality and crime: separating the effects of permanent and transitory income, Oxford Bulletin of Economics and Statistics, 70 (2), $129-153$.

Donohue, J. and Levitt, S. (2001) Le-galized Abortion and Crime, Quarterly Journal of Economics, 116 (2), 379 - 420. 
Edmark, K. (2005) Unemployment and crime: is there a connection? Scandinavian Journal of Economics, 107 (2), 353 - 373.

Ehrlich, I. (1973) Participation in illegitimate activities; a theoretical and empirical investigation, Journal of political Economy, 81 (3), 521 - 565.

Fajnzylber, P., Lederman, D. and Loayza, N. (2002) Inequality and violent crime, Journal of Law and Economics, 45 (1), 1 - 40.

Fleisher, B. M. (1966) The Effect of Income on Delinquency, American Economic Review, 56, 118-137.

Freeman, R. B., 1996 Why do so many young American men commit crimes and what might we do about it? Journal of Economic Perspectives, 10 (1), 25 - 42.

Freeman, R. B. 1999 The economics of crime in Ed by Ashenfelter, O. and Card, D Handbook of Labour Economics, Volume 3 Chapter 52, 3529 - 3571.

Gould, E. D., Weinberg, B. A. and Mustard, D. B. (2002) Crime rates and local labour market opportunities in the United States, Review of Economics and Statistics $84(1), 45-61$.

Imrohoroglu, A., Merlo, A. and Rupert, P. (2000) On the Political Economy of Income Redistribution and Crime, International Economic Review, 41(1), 1-26.

Kelly, M. (2000) Inequality and crime, Review of Economics and Statistics, 82 (4), $530-539$.

Levitt, S. (1997) Using electoral cycles in police hiring to estimate the effect of police on crime, American Economic Review, 87 (3), 270 - 290.

Levitt, S. (2004) Understanding why crime fell in the 1990s: four factors that explain the decline and six that do not, Journal of Economic Perspectives, 18 (1), 163 - 190. 
Machin, S. and Meghir, C. (2000) Crime and economic incentives, The Institute for Fiscal Studies Working paper 00/17.

Raphael, S. and Winter-Ebmer, R. (2001) Identifying the effect of unemployment on crime, Journal of Law and Economics, 44 (1), 259 - 283.

Reilly, B. and Witt, R. (1996) Crime, deterrence and unemployment in England and Wales: an empirical analysis, Bulletin of Economic Research, 48 (2), 137 - 159.

Shavell, S. (1991) Individual precautions to prevent theft: private versus socially optimal behaviour, International Review of Law and Economics, 11, 123-132.

Smith, A. (1937) The Wealth of Nations, New York, Modern Library, 1937.

Williams, K. (1984) Economic Sources of Homicide: Reestimating the Effects of Poverty and Inequality, American Sociological Review, 49, 283-9.

Witte, A. D. and Tauchen, H. 1994, Work and Crime: An Exploration Using Panel data, National Bureau of Economic Research, Cambridge, MA.

Witt, R., Clarke, A. and Fielding, N. (1998) Crime, earnings inequality and unemployment in England and Wales, Applied Economics letters, 5 (4), 265 - 267.

Witt, R., Clarke, A. and Fielding, N. (1999) Crime and economic activity: a panel data approach, British Journal of Criminology, 39(3), 391 - 400. 
Table 1 Random-effects GLS regression for 10 police recorded crimes

\begin{tabular}{|c|c|c|c|c|c|c|c|}
\hline & $\ln$ (Inequality) & $\ln$ (Unemp.) & $\ln ($ Density) & $\ln ($ Detection $)$ & Sigma_u & Sigma_e & Rho \\
\hline $\ln ($ Violence $)$ & $\begin{array}{l}-0.021 \\
(-0.31)\end{array}$ & $\begin{array}{l}0.115 \\
(1.08)\end{array}$ & $\begin{array}{l}0.065^{*} \\
(1.77)\end{array}$ & $\begin{array}{l}-0.264 * * \\
(-2.45)\end{array}$ & 0.058 & 0.091 & 0.290 \\
\hline $\ln ($ Sexual $)$ & $\begin{array}{l}0.108^{*} \\
(1.83)\end{array}$ & $\begin{array}{l}-0.147 \\
(-1.55)\end{array}$ & $\begin{array}{l}0.142 * * * \\
(4.83)\end{array}$ & $\begin{array}{l}0.008 \\
(0.10)\end{array}$ & 0.059 & 0.071 & 0.407 \\
\hline $\ln$ (Robbery) & $\begin{array}{l}0.256 * * * \\
(2.79)\end{array}$ & $\begin{array}{l}0.370 \\
(1.61)\end{array}$ & $\begin{array}{l}0.461 * * * \\
(3.52)\end{array}$ & $\begin{array}{l}-0.775 * * * \\
(-4.16)\end{array}$ & 0.273 & 0.108 & 0.865 \\
\hline $\ln$ (Burglary) & $\begin{array}{l}0.441 * * * \\
(4.27)\end{array}$ & $\begin{array}{l}0.294 \\
(1.28)\end{array}$ & $\begin{array}{l}0.037 \\
(0.40)\end{array}$ & $\begin{array}{l}-0.243 \\
(-1.24)\end{array}$ & 0.153 & 0.102 & 0.691 \\
\hline $\ln$ (Vehicles) & $\begin{array}{l}0.399 * * * \\
(3.53)\end{array}$ & $\begin{array}{l}0.166 \\
(0.67)\end{array}$ & $\begin{array}{l}0.083 \\
(0.88)\end{array}$ & & 0.127 & 0.091 & 0.660 \\
\hline $\ln$ (Theft) & $\begin{array}{l}0.166^{* * * *} \\
(3.46)\end{array}$ & $\begin{array}{l}0.054 \\
(0.47)\end{array}$ & $\begin{array}{l}0.174 * * * \\
(3.13)\end{array}$ & & 0.095 & 0.047 & 0.808 \\
\hline $\ln ($ Fraud $)$ & $\begin{array}{l}0.616 * * * \\
(4.32)\end{array}$ & $\begin{array}{l}-0.386^{*} \\
(-1.91)\end{array}$ & $\begin{array}{l}0.076 \\
(0.90)\end{array}$ & $\begin{array}{l}-0.873 * * * \\
(-4.51)\end{array}$ & 0.054 & 0.149 & 0.115 \\
\hline $\ln$ (Damage) & $\begin{array}{l}-0.004 \\
(-0.08)\end{array}$ & $\begin{array}{l}-0.067 \\
(-0.59)\end{array}$ & $\begin{array}{l}-0.107 * * \\
(-2.01)\end{array}$ & $\begin{array}{l}-0.373 * * * \\
(-3.70)\end{array}$ & 0.115 & 0.061 & 0.779 \\
\hline $\ln$ (Drug) & $\begin{array}{l}-0.243 * * \\
(-2.53)\end{array}$ & $\begin{array}{l}0.534 * * \\
(2.38)\end{array}$ & $\begin{array}{l}0.195^{*} \\
(1.89)\end{array}$ & $\begin{array}{l}1.536 * * \\
(2.09)\end{array}$ & 0.193 & 0.101 & 0.784 \\
\hline $\ln$ (Other) & $\begin{array}{l}-0.140 * * \\
(-2.21)\end{array}$ & $\begin{array}{l}0.363 * * * \\
(2.67)\end{array}$ & $\begin{array}{l}0.031 \\
(0.57)\end{array}$ & $\begin{array}{l}0.271 \\
(1.29)\end{array}$ & 0.109 & 0.089 & 0.600 \\
\hline
\end{tabular}

Note: $*$ significant at $10 \%$ level; $* *$ significant at $5 \%$ level; $* * *$ significant at $1 \%$ level. Figures in parentheses are $\mathrm{t}$ ratios. Sigma_u and sigma_e denote the panel-level variance component and the overall variance respectively. Rho is the percent contribution to the total variance of the panel-level variance component. When rho equals zero, the panel estimator is no different from the pooled estimator. 
Table 2 Fixed-effects (within) regression for 10 police recorded crimes

\begin{tabular}{|c|c|c|c|c|c|c|}
\hline & $\ln$ (Inequality) & $\ln ($ Unemployed) & $\ln$ (Detection) & Sigma_u & Sigma_e & Rho \\
\hline $\ln ($ Violence $)$ & $\begin{array}{l}-0.145^{* *} \\
(-2.23)\end{array}$ & $\begin{array}{l}-0.448 * * * \\
(-2.71)\end{array}$ & $\begin{array}{l}-0.267 * * \\
(-2.61)\end{array}$ & 0.221 & 0.092 & 0.852 \\
\hline $\ln ($ Sexual $)$ & $\begin{array}{l}0.046 \\
(0.74)\end{array}$ & $\begin{array}{l}-0.362^{* *} \\
(-2.53)\end{array}$ & $\begin{array}{l}0.029 \\
(0.40)\end{array}$ & 0.185 & 0.079 & 0.846 \\
\hline $\ln$ (Robbery) & $\begin{array}{l}0.237 * * \\
(2.51)\end{array}$ & $\begin{array}{l}0.368 \\
(1.43)\end{array}$ & $\begin{array}{l}-0.722 * * * \\
(-3.72)\end{array}$ & 0.547 & 0.139 & 0.939 \\
\hline $\ln$ (Burglary) & $\begin{array}{l}0.429 * * * \\
(3.79)\end{array}$ & $\begin{array}{l}0.246 \\
(0.83)\end{array}$ & $\begin{array}{l}-0.181 \\
(-0.85)\end{array}$ & 0.171 & 0.165 & 0.516 \\
\hline $\ln$ (Vehicles) & $\begin{array}{l}0.384 * * * \\
(3.05)\end{array}$ & $\begin{array}{l}0.103 \\
(0.31)\end{array}$ & & 0.157 & 0.185 & 0.418 \\
\hline $\ln$ (Theft) & $\begin{array}{l}0.169 * * * \\
(3.31)\end{array}$ & $\begin{array}{l}0.086 \\
(0.64)\end{array}$ & & 0.195 & 0.075 & 0.871 \\
\hline $\ln ($ Fraud $)$ & $\begin{array}{l}0.643 * * * \\
(3.77)\end{array}$ & $\begin{array}{l}-0.429 \\
(-0.96)\end{array}$ & $\begin{array}{l}-1.002 * * * \\
(-3.82)\end{array}$ & 0.100 & 0.249 & 0.138 \\
\hline $\ln$ (Damage) & $\begin{array}{l}-0.047 \\
(-1.01)\end{array}$ & $\begin{array}{l}-0.298 * * \\
(-2.42)\end{array}$ & $\begin{array}{l}-0.361 * * * \\
(-3.82)\end{array}$ & 0.219 & 0.069 & 0.911 \\
\hline $\ln ($ Drug $)$ & $\begin{array}{l}-0.263 * * \\
(-2.49)\end{array}$ & $\begin{array}{l}0.470 * \\
(1.71)\end{array}$ & $\begin{array}{l}1.551 * \\
(1.98)\end{array}$ & 0.236 & 0.154 & 0.702 \\
\hline $\ln ($ Other $)$ & $\begin{array}{l}-0.198 * * * \\
(-3.16)\end{array}$ & $\begin{array}{l}0.089 \\
(0.54)\end{array}$ & $\begin{array}{l}0.142 \\
(0.69)\end{array}$ & 0.199 & 0.091 & 0.825 \\
\hline
\end{tabular}

See note of Table 1 
Table 3 Random-effects GLS regression for $\ln ($ Robbery)

\begin{tabular}{|c|c|c|c|}
\hline & Specification 1 & Specification 2 & Specification 3 \\
\hline $\ln$ (Inequality) & $\begin{array}{l}0.220 * * \\
(2.02)\end{array}$ & $\begin{array}{l}0.227 * * \\
(2.20)\end{array}$ & $\begin{array}{l}0.256^{* * * *} \\
(2.79)\end{array}$ \\
\hline $\ln$ (Unemployment) & $\begin{array}{l}0.701 * * \\
(2.57)\end{array}$ & $\begin{array}{l}0.569 * * \\
(2.20)\end{array}$ & $\begin{array}{l}0.370 \\
(1.61)\end{array}$ \\
\hline $\ln$ (Density) & & $\begin{array}{l}0.566^{* * *} \\
(3.42)\end{array}$ & $\begin{array}{l}0.461 * * * \\
(3.52)\end{array}$ \\
\hline $\ln ($ detection $)$ & & & $\begin{array}{l}-0.775 * * * \\
(-4.16)\end{array}$ \\
\hline Constant & $\begin{array}{l}-0.665 \\
(-1.43)\end{array}$ & $\begin{array}{l}-3.820 * * * \\
(-3.80)\end{array}$ & $\begin{array}{l}-0.417 \\
(0.37)\end{array}$ \\
\hline Sigma_u & 0.538 & 0.358 & 0.273 \\
\hline Sigma_e & 0.156 & 0.121 & 0.108 \\
\hline Rho & 0.922 & 0.898 & 0.865 \\
\hline $\begin{array}{l}\text { Wald chi2 } \\
\text { Prob > chi2 }\end{array}$ & $\begin{array}{l}8.11 * * \\
0.017\end{array}$ & $\begin{array}{l}21.44 * * * \\
0.000\end{array}$ & $\begin{array}{l}51.85^{* * *} \\
0.000\end{array}$ \\
\hline $\begin{array}{r}\text { R-square: within } \\
\text { between } \\
\text { overall }\end{array}$ & $\begin{array}{l}0.120 \\
0.177 \\
0.171\end{array}$ & $\begin{array}{l}0.082 \\
0.794 \\
0.761\end{array}$ & $\begin{array}{l}0.295 \\
0.862 \\
0.835\end{array}$ \\
\hline
\end{tabular}

See note of Table 1. 